\title{
Koltxizina eta gaixotasun kardiobaskularra
}

Ohiko tratamenduari koltxizina gehitzea eraginkorra izan daiteke kardiopatia iskemikoaren bigarren mailako prebentzioan

Gako-hitzak: koltxizina, kardiopatia iskemikoa, 2. mailako prebentzioa

\section{Colchicine and cardiovascular disease}

Adding colchicine to normal treatment may be effective in secondary prevention of ischemic cardiopathy

Key words: colchicine, ischemic cardiopathy, secondary prevention

\section{Jatorrizko erreferentzia}

Nidorf SM, Fiolet ATL, Mosterd A, Eikelboom JW, Schut A, Opstal TSJ, The SHK, Xu XF, Ireland MA, Lenderink T, Latchem D, Hoogslag P, Jerzewski A, Nierop P, Whelan A, Hendriks R, Swart H, Schaap J, Kuijper AFM, van Hessen MWJ, Saklani P, Tan I, Thompson AG, Morton A, Judkins C, Bax WA, Dirksen M, Alings M, Hankey GJ, Budgeon CA, Tijssen JGP, Cornel JH, Thompson PL; LoDoCo2 Trial Investigators. Colchicine in Patients with Chronic Coronary Disease. N Engl J Med. 2020 Nov 5; 383(19):1838-1847. doi: 10.1056/NEJMoa2021372.

\section{Kritikoki aztertutako testuaren egileak}

Mikel Moreno. Irurtzungo Osasun Zentroa.mikel.bakedano@gmail.com Ana Gorroñogoitia. Bizkaiko Irakaskuntzako Unitatea. aigorrono@gmail.com Idoia Alcorta. Bidasoa Ospitalea. mirenidoia.alcortamichelena@osakidetza.eus Ina Idarreta. Tolosako Osasun Zentroa. ina.idarretamendiola@osakidetza.eus

\section{Galdera, 3 osagaiekin}

Pazienteak: 35-82 urteko adinekoak, gaixotasun koronarioa dutenak (angiografia edo kaltzio koronarioa $>400$ AgatstonTAKean) klinikoki egonkorrak $>6$ hilabete. Giltzurruneko gutxiegitasun moderatu-larria, gaixotasun balbular larria eta bihotzeko gutxiegitasun larria duten pertsonak baztertzen dituzte. Esku-hartzea/konparazioa: koltxizina $0,5 \mathrm{mg} /$ egunean behin vs plazebo berdina.

\section{Aztertutako aldagaiak}

-Aldagai nagusia : hilkortasun kardiobaskularra eta miokardio-infartua eta iktus ez-hilgarria edo birbaskularizazio koronarioa konbinatuta. Analisi nagusia aldagai konposatuaren edozein osagairen 1. gertakarira arteko denboran oinarritu zen.

- Bigarren mailako aldagaiak, aurrez zehaztutakoak, bai eta azpitaldeak ere. 


\section{Azterlanaren analisia}

Entsegu klinikoa; koltxizina plazeboarekin kontrolatuta. Ausazkotua. Ausazko sekuentzia ezkutatua. Tratatzeko asmoaren araberako analisia. Jarraipenaren batez bestekoa, 28,6 hilabete. Pazienteen \% 10,5eko galera talde bakoitzean.

Laginaren tamaina, \% 90eko potentziarako kalkulatua, gertaeretan \% 30eko aldea hautematea, jarraipena egiteko \% 10eko galerak onartzea eta kontrol-taldean aldagai konbinatuaren \% 2,6ko gertakari-tasa izatea.

Ez dago alde nabarmenik bi taldeen oinarrizko ezaugarrietan.

Baztertutakoak: giltzurruneko gaixotasun moderatu-larria, bihotzeko gutxiegitasun larria eta patologia balbular larria, bai eta koltxizina gisa ezagutzen diren kontrako efektuak dituzten pertsonak ere.

Biziraupenaren azterketa egin da.

Pazienteak

- Kontrol-taldea $(n=2760)$

- Talde esperimentala $(n=2762)$

Emaitzak

\begin{tabular}{|c|c|c|c|c|c|c|}
\hline & Jarraipena & CER & EER & HR & TBK & $\mathbf{P}$ \\
\hline \multirow[b]{2}{*}{ Aldagai nagusia } & 28,6 hilabete & 0,096 & 0,068 & 0,69 & 35 & $<0,001$ \\
\hline & \multicolumn{3}{|c|}{ \% 95eko konfiantza-tartea } & $\begin{array}{l}0,57- \\
0,83\end{array}$ & $\begin{array}{c}25- \\
64\end{array}$ & \\
\hline \multirow{2}{*}{$\begin{array}{l}\text { Ondorio } \\
\text { kaltegarriak }\end{array}$} & $\begin{array}{l}\text { Bihotz-hodietakoez besteko } \\
\text { hilkortasuna }\end{array}$ & 0,5 & 0,7 & & & \multirow{2}{*}{$\mathrm{EE}$} \\
\hline & $\begin{array}{c}\text { Digestio-aparatuko arazoengatiko } \\
\text { ospitaleratzeak }\end{array}$ & 0,7 & 0,7 & & & \\
\hline
\end{tabular}

CER kontrol-taldeko arriskua, EER esperimentu-taldeko arriskua, TBK tratatu beharreko kopurua HR Hazard ratioa, EE ez esanguratsua

\section{Iruzkinak}

Azterketaren kalitatea ona da (Jadad 5). Bi taldeetan, \% 84k gertaera koronario akutua izan zuen aleatorizazioaren aurreko 24 hilabeteetan.

Aipatu behar da azterketaren aurreko fasean, egileek baztertu egin zituztela koltxizina onartzen ez zuten pazienteak.

Koltxizinak 0,5 mg/egunean behineko dosian, kardiopatia iskemiko egonkorraren tratamenduari gehituta, murriztu egiten du hilkortasun kardiobaskularraren, infartuaren edo iktus ez-hilgarrien aldagai konbinatua. Emaitzak sendoak dira aldagai konposatuaren osagai bakoitzean, bai eta adinaren, tabakoaren, HTAren, diabetesaren, giltzurruneko gaixotasunaren, estatina-dosiaren edo ezetimibaren erabileraren arabera aurrez zehaztutako azpitaldeetan ere. Estatistikoki aldeak esanguratsuak izan ez baziren ere, hilkortasun ez-kardiobaskular handiagoa eta digestio-aparatuko nahasmenduen ondoriozko ospitaleratze gehiago izan ziren koltxizina-taldean.

Egileek adierazi dute koltxizinak paziente horiengan duen onura bigarren mailako prebentzioan (estatinak, antihipertentsiboak edo antiagregatzaileak) beste farmako batzuk erabiltzeak dakarrenaren baliokidea dela. Halaber, azpimarratu dute onura horrek ez duela behera egiten 5 urtean jarraipena egin izan zieten pazienteengan.

Azpimarratu nahi genuke azterlan bat besterik ez dela, eta interesgarria izango litzatekeela ondorengo saiakuntzetan efektuaren sendotzea. 